\title{
Institutional logics and organizational change: the role of place and time
}

\author{
Diego Ponte ${ }^{1}$ (D) $\cdot$ Caterina Pesci $^{1}$
}

Accepted: 26 April 2021 / Published online: 8 May 2021

(c) The Author(s) 2021

\begin{abstract}
This paper investigates the case of a hybrid organization located in Northern Italy with the aim of providing an understanding of the role of the context, defined in terms of 'place' and 'time', in shaping organizational changes. A dynamic institutional approach focused on both 'place' and 'time' as key explanatory factors can provide a valuable framework to understand both the changing institutional demands on the firm and the rationalities behind the changes that occur at organizational, strategic and governance level. Consequently, this paper aims to contribute to the institutional logics literature by describing how these two contextual elements can be used to interpret institutional logic pressures on the organization under investigation as well as govern changes at micro level. The results indicate that the changes were produced by dynamics that are exogenous and endogenous to the organization in the case study and strongly influenced by the context in which it operates. The paper also highlights how changes in terms of service provision, accountability and organizational setting are the results of the 'place' and 'time' in which these events occur.
\end{abstract}

Keywords Institutional logics $\cdot$ Hybrid organizations $\cdot$ Time $\cdot$ Place $\cdot$ Management accounting systems $\cdot$ Organizational change

\section{Introduction}

The paper adopts an institutional logic perspective (Thornton et al. 2012) to investigate the changes in terms of governance, strategy and operations which occurred within a hybrid firm located in Northern Italy during a period of almost 9 years; these changes are to be considered as the result of a longer period of normative changes and debates at different levels. Indeed, the history and changes of the firm

Diego Ponte

diego.ponte@unitn.it

Caterina Pesci

caterina.pesci@unitn.it

1 Department of Economics and Management, University of Trento, Via Inama 5, Trento, Italy 
under investigation must be inserted in the broader context of the European reforms aimed at effectively managing the relationship between competition and public economic activity (Janssen, 2014). Since the 1990s, regional, national and international bodies in Europe introduced various reforms of the public sector in order to guarantee freedom of movement and fair competition in the European market. The declared intention of such reforms was to preserve and balance different principles such as economic efficiency, competition and equality in the provision of goods and services (Manunza \& Berends, 2013). These evolving norms at different levels caused significant changes in terms of strategies, governance, organizational setting and ownership of the firms run by public institutions. This normative approach was the result of a geo-political equilibrium established over time within the boundaries of Europe, its member states and their local territories (Cafruny and Magnus, 2003; Raik, 2016; Pänke, 2019).

By using an institutional logic approach in this paper, the authors investigate the role of the context as a key element to explain both the changes and the balance between different institutional logics, where the context has been defined as the interplay of the place and time in which an organization operates (Quattrone, 2015; Suddaby, 2010, 2015). The place influencing an organization can be defined at different levels by considering the geo-political equilibrium (Lawrence \& Dover, 2015) and the related equilibrium of powers during a given time (Mangez \& Liénard, 2015; Dubois, 2014; Bourdieau, 1996), while time should not be considered a fixed measure but rather a malleable dimension in which negotiations occur (Dawson \& Sykes, 2019) and which owns specific historical nuances (Suddaby, 2015). Hence, individuals and organizations interact in fields characterized by different historical timeframes and temporal logics which apply to different places.

Achieving an understanding of the complexity of the logics and the role of the context as the combination of time and place in which organizations operate is a key issue to unveil how the balance of different logics can shape the changes within organizations (Kellog, 2009; Quattrone, 2015; Suddaby, 2015; Dunn \& Jones, 2010).

Due to the paramount role of the interplay between time and place in potentially explaining the interaction between different logics and their impact on organizations, this study aims to answer the following questions: (1) how do the external demands from different places during a specific timeframe influence the equilibrium between the logics; and (2) how does the new equilibrium affect the change(s) in organizations?

This paper contributes to the existing literature on hybrid organizations by advancing previous institutional logics studies which underestimated the role of the context, understood in terms of 'place' and 'time', as dynamic elements shaping inter-institutional systems.

The paper is organized as follows: Sect. 2 reviews the literature of institutional logics theory and hybrid organizations; Sect. 3 describes the methods of the study while Sect. 4 describes the details and analysis of the case study. 


\section{Literature review}

\subsection{Institutional theories}

Institutional theories are a broad research field that encompasses different theoretical and methodological aspects (Greenwood et al., 2017). A substantial part of these institutional theories has addressed the mechanisms for building institutionalization by highlighting how these mechanisms work to reinforce the prevailing social order or to replace it with another (DiMaggio \& Powell, 1991; Meyer \& Rowan, 1977; Thornton, 2004; Thornton \& Ocasio, 1999, 2008). Other authors have studied the development and trends in the use of institutional theory in management sciences (Micelotta et al., 2017).

A relatively recent development in this field is the 'metatheory' of institutional logics. Institutional logics are a socially constructed set of practices, beliefs, rules and systems by which organizations and individuals make sense of their social reality and act accordingly (Thornton et al., 2012). At the core of institutional logics lies the concept of "institutional order" which was initially defined as a:

... domain of institutions built around a cornerstone institution that represents the cultural symbols and material practices that govern a commonly recognized area of life. Each institutional order represents a governance system that provides a frame of reference that preconditions actors' sensemaking choices. (Thornton et al. 2012, p. 54).

However, the use of the institutional logics perspective in management studies has been criticised because the majority of these works seem to adopt static and mechanistic approaches. In contrast to these approaches, many scholars identified an endogenous dynamism residing in the logics themselves: this type of dynamism had not been recognised in previous studies, which "... become inattentive to the places and times in which order is formed and logics operate" (Quattrone, 2015 , p. 40). On this basis, the current literature conceives institutional logics as 'substantive', which implies that changes and dynamism are the result of competing logics and their recombination. On the other hand, viewing the logics as 'procedural' provides the opportunity to observe them from how things are done, considered "inextricably linked to why they are done" (Quattrone, 2015). Such observation underlines the importance of analysing the contextual variables in which actors/organizations operate: these have been considered as 'places' and 'time' (Granqvist \& Gustafsson, 2016; Lawrence \& Dover, 2015). The need of exploring contextual nuances derives from the fact that "institutional theory has become a-historical substituting a complex and nuanced construct (i.e., history) with a discrete and measurable proxy (time)" while "... the complex causality of history is reduced to the overly simplistic variable of time" (Suddaby, 2015, p. 94).

Thus, locating the studies based on institutional logic in a historical context, defined in terms of place and time, can help to achieve a more nuanced understanding of the dynamics of organizational changes. 


\subsubsection{Place and time in institutional theories}

When studying place in the institutional theory arena, the geographical meaning of the concept and the broader meaning of physical and conceptual location merge. A place is a meaningful location that allows institutions to persist and maintain meaning among actors while avoiding dangerous drifts (Cresswell, 2004), and each institution operates within the boundaries of such a place (Dacin et al., 2011). While traditional literature placed importance on the role of places in maintaining institutions and rituals, recent literature has focused on the role of places as factors that hinder/facilitate institutional change and innovation (Suddaby, 2010, 2015). Indeed, places in which actors and institutions interact may have a profound impact on the evolution of such interaction. Scholars have identified different places; for example, interstitial spaces as generators of new practices (Furnari, 2014), experimental spaces as temporary settings where the emotions of actors play a role towards institutional innovation (Cartel et al., 2019) and relational spaces where places play a role of facilitators/obstacles of actors' interaction (Lawrence \& Dover, 2015). Indeed, the concept of place in institutional literature might be considered as "the intersection of a geographic location, a set of meanings and values and a material form" (Lawrence \& Dover, 2015, p. 371). Social geography does provide some key issues when considering the relationship between place and institutions, among which the issue of scale plays a paramount role and setting the boundaries of place can indeed imply a reference to the whole earth or to territorial units (Brenner, 2004).

Even if the notion of place has been distinguished from that of field (Lawrence \& Dover, 2015) based on its stronger connection with geographical location influencing meanings and values, it embodies many issues connected with the field theories. One key issue embodied in both notions is connected with the role of power and politics or geo-politics: the role of power, and consequently of politics, has been studied in the field theory realm (Mangez \& Liénard, 2015; Dubois, 2014). Indeed, the process of the formation of any given field must be understood as a process of power (Bourdieu, 1996) and politics do represent one key expression of power in society.

In this regard, the equilibrium between competition and public economic activity within the boundary of Europe, the single European countries and their local territories needs to be settled in a particular political environment (place) and its history. The equilibrium between the aforementioned economic choices (competition and public economic activity) historically originated from an equilibrium of the powers of opposite geo-political forces or factions-one dominated by Neoliberalism and the other by the Marxism ideologies. In particular, the European Union is the result of an integration containing "power relations and efforts to mediate and contain conflict in order to produce a social order... a transnational neoliberal socioeconomic order" (Cafruny and Ryner, 2003, p. 5). Indeed, Europe can be a place within the territories which have been strongly influenced by Neoliberalism ideas since the beginning of the process of integration. The acceptance of neoliberalist ideas within the boundaries of Europe can be considered "an evolving hybrid whose concrete manifestation is imbued with local flavours" (Ban, 2016, p. 3). The local dimension of the neoliberalism acceptance and its evolutionary and local features 
are key factors in understanding how some types of organizations have evolved and been shaped in the last decades within the boundaries of Europe.

Places are not the only important conditioning factors in the shaping of institutional changes (Kellogg, 2009) because socio-political/economic relations and conditions develop and evolve in different timeframes in relation to particular historical conditions (Pänke, 2019; Raik, 2016). While time has been explored in management research as an unambiguous physical unit, less attention has been given to its negotiated dimension (Dawson \& Sykes, 2019). Time should not be considered as a fixed measure but a malleable one. Literature shows that individuals and organizations confer and interact in fields with different timeframes and temporal logics, thus time should be considered a mediated window of opportunity for institutional change or a cornerstone for decisions (Granqvist \& Gustafsson, 2016). Time can also be seen as an "ambitemporality" variable where organizations and institutions may reconstruct and use different notions of time (Reinecke \& Ansari, 2015; Slawinski \& Bansal, 2015). The historical perspective is another nuance of the element of time that helps in achieving a deeper understanding of the decisions which occurred in a certain geo-political area (Pänke, 2019; Raik, 2016): this perspective allows scholars to consider and embed the complex causality of history in their analysis (Suddaby, 2015).

Nonetheless, an inter-institutional system made up of different logics, its contradictions and its need of a balance per se, does not provide a satisfactory explanation of the dynamism and changes which occur in organizations. The dynamism, which is not explained by the interplay between logics, has been investigated as the paradox of the embedded agency and often the paradox has been solved by appealing for the intervention of institutional entrepreneurship. The introduction of institutional entrepreneurship, however, has been criticised because it has been used as a deus ex machina to explain whatever institutional theories fail to (Suddaby, 2015). Hence, it seems plausible that the dynamic balance of forces within and across organizations should be placed and considered in a context defined in terms of the place and time able to influence the balance itself as well as shape the institutional entrepreneurship.

\subsection{Hybrid organizations}

The study of hybrid organizations has gained attention from management, organization and accounting scholars (Ahrens \& Chapman, 2007; Bagnoli \& Megali, 2011; Battilana \& Lee, 2014; Busco et al., 2017; Mair et al., 2015; Nicholls, 2009; Ramus \& Vaccaro, 2017).

The number and purpose of hybrid organizations abound and, in the literature, it is possible to distinguish them by using different taxonomies or theories (Ebrahim et al., 2014; Koppell, 2003; Ménard, 2004). The majority of hybrid organizations are providers of services with various social reverberations in substitution, jointly or on behalf of the state and/or local governments (Minkoff, 2002). While hybridity is considered an inevitable and permanent characteristic of social enterprises (Brandsen et al., 2005), the same argument is valid when investigating the public sector where the interest of the community is usually pursued by taking into consideration elements of other, often 
conflicting, institutional logics (Skelcher \& Smith, 2015). Conflicting institutional logics operate simultaneously in this type of organization (Jay, 2013).

When analysing the forces influencing such organizations, scholars state that organizational complexity often generates an opposition between at least two different logics but this imbalance might be solved by harmonization (Busco et al., 2017; Canales, 2014; Jay, 2013; Ramus et al., 2017). In an effort to gain an equilibrium state, changes in and among institutional logics may occur (Glynn \& Lounsbury, 2005; Nigam \& Ocasio, 2010) and these have recently been considered triggers of change at organizational level (Jay, 2013; Canales, 2014; Mair et al., 2015; Teixeira et al., 2017). Thornton et al. (2012) also identified conditions that make organizational change possible by acting on the equilibrium among competing logics, some of which are technological changes, economic crises and social upheaval, occurrence of salient events and changes in management attitudes. Another condition potentially able to influence changes at different field levels is the cultural capital (Bourdieu, 1996) owned by organizations that can be shaped or transformed by adopting specific instruments e.g., management accounting tools recognised as capable of modifying organizational culture (Ax \& Greve, 2017; Busco \& Scapens, 2011). Organizational cultural capital, indeed, is strongly influenced by the individual background of those operating at the organizational field level (Mangez \& Liénard, 2015) and the different type of performance measurement systems adopted can support strategic decision and legitimate management actions (Henri, 2006). Thus, scholars have highlighted the relationship between strategies, culture, and management accounting systems since these latter are able to drive cultural organizational changes according to the strategies of the firms (Ax \& Greve, 2017; Baird et al., 2004, 2007, 2018; Cinquini \& Tenucci, 2010; Zhang et al., 2015). The possibility of legitimizing an administration decision-making process based on the prevalence of one logic over another is indeed particularly needed in hybrid contexts. Therefore, in this paper changes generated by institutional logics dynamism can be interpreted by considering the combination of the place and time in which they operate. The observed actions and counteractions of actors and institutions affect the process of change and structuration of a hybrid organization in terms of governance, strategy and organizational setting. The focus of the present analysis is on changes arising within the organization as a new equilibrium of logics dependent on the peculiarity of the place in which the organization is located during a particular historical time.

\section{Methods}

From a methodological viewpoint, this study adopts a longitudinal analysis approach based on several sources and on the engagement with the case study organization as the object of the research (Myers, 2013; Yin, 2003).

\subsection{Data collection}

Data collection is based on qualitative techniques that include primary data sources (Sects. 3.1.2 and 3.1.3) and secondary data sources (Sects. 3.1.1). 


\subsubsection{Archival documents}

The authors constructed an archive of documents containing official financial and non-financial documents of the firm-the statute, the financial statement, financial and non-financial internal reports, official press releases as well as newspapers articles, books, international and national laws and other institutional documents. This secondary data was used to examine the institutional dynamics around and within the firm and the changes regarding its strategic, governance and organizational dimensions. (Krippendorff, 2004).

The authors identified a list of 153 articles from the two main local newspapers over a specific period of change, namely 1997-2006 (Table 1). This period is particularly relevant as it covers the main institutional changes in Europe during the transition to the single European market undertaken by the European institutions. The articles were categorized according to the main keywords which symbolise the market and the state institutional logics (Table 1). Such categorization followed three steps: first, an external person unaware of the research goals browsed the local newspapers in search for articles about the organization in question, ServiceCo. The said person then produced a summary for each of the 153 articles. The two authors of this paper separately analysed and categorized the articles, and then triangulated their findings into a shared categorization.

\subsubsection{Participant observation}

The archive of documents was complemented by primary data obtained from direct observation of the firm. Access to this data was granted from 2003 because one of the authors had been an academic consultant to the firm together with one of the interviewed persons (Sect. 3.1.3). The role of the interviewee as an expert in the construction of a management accounting system is particularly relevant to this paper (Sect. 4.2). This personal interactive participation provided the researcher with the opportunity to cooperate with key managers and other designated staff: part of this activity is reported in the official public and private documents held by the firm.

\subsubsection{Formal interviews}

Three qualitative interviews were conducted with a key manager and an academic consultant after the period of participant observation. These interviews were recorded and subsequently transcribed. The manager (hereafter interviewee 1) who had played a fundamental role in the creation of the management accounting system was interviewed twice, in 2013 and 2016. The third interview was held with the academic expert (interviewee 2) who had been involved for over a decade as a strategic and business consultant. He played a special role in the creation of the management accounting system as described in Sect. 4.2 (interviewed in 2016). The scripted interviews were coded (Huberman \& Miles, 1994; 
Table 1 Newspaper articles about ServiceCo over the period 1997-2006

\begin{tabular}{|c|c|c|}
\hline Date & Newspaper & Title \\
\hline 27/03/1997 & L'Adige & Informatica Trentina rafforza il bilancio \\
\hline 03/04/1997 & L'Adige & Informatica Trentina quadruplica l'utile \\
\hline $12 / 04 / 1997$ & L'Adige & Informatica Trentina aumenta il capitale \\
\hline 22/01/1998 & L'Alto Adige & Informatica Trentina e il mistero Fulcrum \\
\hline 22/01/1998 & L'Adige & Check up su bilanci e strategie di Informatica Trentina \\
\hline 21/02/1998 & L'Alto Adige & Informatica Trentina snella \\
\hline 21/02/1998 & L'Adige & Informatica Trentina, sale il fatturato \\
\hline 28/02/1998 & L'Alto Adige & Informatica Trentina, la partita di potere \\
\hline 05/03/1998 & L'Adige & Informatica Trentina rallentata dalla politica \\
\hline 22/03/1998 & L'Alto Adige & Informatica Trentina entra nel limbo \\
\hline 01/04/1998 & L'Alto Adige & Informatica Trentina, per il nuovo Cda nomine sospese \\
\hline $12 / 05 / 1998$ & L'Alto Adige & Informatica Trentina, giochi di potere \\
\hline 02/07/1998 & L'Adige & Informatica Trentina, dibattito aperto \\
\hline 08/04/1999 & L'Adige & Informatica Trentina procede a gonfie vele \\
\hline 25/05/1999 & L'Adige & Informatica Trentina, cerchi nuovi clienti \\
\hline 31/08/1999 & L'Adige & Informatica Trentina punta sul turismo \\
\hline 05/11/1999 & L'Adige & Dismissione di Informatica Trentina, ecco il piano \\
\hline 13/11/1999 & L'Adige & Dismissione di Informatica Trentina, pesanti dubbi del sindacato \\
\hline 26/11/1999 & L'Adige & Privatizzazioni senza strategie \\
\hline 04/01/2000 & L'Adige & Informatica Trentina, i dirigenti vogliono il $51 \%$ \\
\hline $05 / 01 / 2000$ & L'Adige & Informatica Trentina "offerta interessante" \\
\hline 06/01/2000 & L'Adige & Informatica Trentina, una folla di pretendenti \\
\hline $11 / 01 / 2000$ & L'Adige & Informatica Trentina, venerdì il vertice dell'Unione \\
\hline $12 / 01 / 2000$ & L'Alto Adige & Informatica Trentina, privatizzazione "amica" \\
\hline $13 / 01 / 2000$ & L'Alto Adige & Informatica Trentina, sindacati pronti allo scontro \\
\hline $13 / 01 / 2000$ & L’Adige & No alla privatizzazione \\
\hline $14 / 01 / 2000$ & L'Adige & Informatica Trentina, Argentea con Seac e Delta \\
\hline $14 / 01 / 2000$ & L'Adige & E i dirigenti rilanciano l'offerta \\
\hline $14 / 01 / 2000$ & L'Alto Adige & Informatica Trentina, manager decisi \\
\hline $15 / 01 / 2000$ & L'Alto Adige & Informatica Trentina, una privatizzazione vuota? \\
\hline $15 / 01 / 2000$ & L'Adige & Informatica Trentina, Bort sonderà la Provincia \\
\hline 21/01/2000 & L'Adige & Informatica Trentina, Bort incontra i politici \\
\hline $23 / 01 / 2000$ & L'Alto Adige & L’Unione vuole Informatica Trentina \\
\hline 23/01/2000 & L’Adige & Informatica Trentina, stringere i tempi \\
\hline $25 / 01 / 2000$ & L'Alto Adige & $\begin{array}{l}\text { Infostrutture, Finsiel ha dato il via libera / Informatica Trentina, } \\
\text { un'occasione per le imprese }\end{array}$ \\
\hline $25 / 01 / 2000$ & L'Adige & Prime garanzie per l’Unione \\
\hline 02/02/2000 & L'Adige & Informatica Trentina non sarà svuotata, sindacati soddisfatti \\
\hline $16 / 02 / 2000$ & L'Alto Adige & Informatica Trentina: troppi silenzi sulla privatizzazione amica \\
\hline $16 / 02 / 2000$ & L'Adige & Le opposizioni e Informatica Trentina \\
\hline $22 / 02 / 2000$ & L'Adige & Informatica Trentina si riorganizza, la Cisl accusa \\
\hline $24 / 02 / 2000$ & L'Alto Adige & Informatica Trentina, l’ipotesi di Dellai \\
\hline $26 / 02 / 2000$ & L'Alto Adige & Il nodo informatico \\
\hline
\end{tabular}


Table 1 (continued)

\begin{tabular}{|c|c|c|}
\hline Date & Newspaper & Title \\
\hline $14 / 03 / 2000$ & L'Alto Adige & Informatica Trentina, progetto paralizzato \\
\hline $09 / 05 / 2000$ & L'Alto Adige & Informatica Trentina, conti in ordine ma il futuro è Infostrutture \\
\hline $10 / 05 / 2000$ & L'Adige & Informatica Trentina investe su e-business e comunicazioni \\
\hline $23 / 05 / 2000$ & L'Adige & Argentea, un fronte per Informatica Trentina \\
\hline $22 / 06 / 2000$ & L'Alto Adige & Informatica Trentina, taglio miliardario ai prezzi \\
\hline $01 / 07 / 2000$ & L'Adige & Informatica Trentina, sì al mercato \\
\hline $01 / 07 / 2000$ & L'Adige & I privati chiedono più concorrenza \\
\hline $27 / 10 / 2000$ & L'Alto Adige & Soluzione Podini per Infostrutture in crisi \\
\hline $27 / 10 / 2000$ & L'Adige & Informatica Trentina, Dellai accelera la privatizzazione \\
\hline $03 / 11 / 2000$ & L'Alto Adige & Infostrutture Trentina, il timone passa a Trentino Servizi \\
\hline $04 / 11 / 2000$ & L'Adige & Infostrutture, altro $28 \%$ a Trentino Servizi \\
\hline $05 / 11 / 2000$ & L'Adige & Informatica Trentina il ddl torna in aula \\
\hline $10 / 11 / 2000$ & L'Alto Adige & E Informatica Trentina rimane al palo \\
\hline $08 / 12 / 2000$ & L'Adige & Infostrutture, transazione da 700 milioni \\
\hline $16 / 12 / 2000$ & L'Alto Adige & Informatica Trentina esige chiarezza \\
\hline $23 / 12 / 2000$ & L'Adige & Dellai con Dalpez, il Trentino sia più unito \\
\hline $13 / 01 / 2001$ & L'Adige & Le ventidue leggi in attesa \\
\hline $02 / 03 / 2001$ & L'Adige & Informatica Trentina, vendita e consiglio congelato \\
\hline $16 / 03 / 2001$ & L'Adige & Informatica Trentina, si va verso la gara \\
\hline $27 / 03 / 2001$ & L'Adige & Informatica Trentina, si va verso la privatizzazione \\
\hline $28 / 03 / 2001$ & L'Adige & Dipendenti in agitazione \\
\hline $29 / 03 / 2001$ & L'Adige & Informatica Trentina, è stallo \\
\hline $08 / 05 / 2001$ & L'Adige & Informatica Trentina, nuovo studio sulla privatizzazione \\
\hline $29 / 05 / 2001$ & L'Adige & Informatica Trentina, la protesta blocca l'aula \\
\hline $30 / 05 / 2001$ & L'Adige & Informatica Trentina, protocollo sulle garanzie \\
\hline $31 / 05 / 2001$ & L'Adige & Quella solidarietà mafiosa \\
\hline 05/06/2001 & L'Adige & Dellai apre, il centro destra chiude \\
\hline 06/06/2001 & L'Adige & E ora Dellai ritiri la proposta \\
\hline 08/06/2001 & L'Adige & Informatica Trentina, sul Cda la giunta decide entro lunedì \\
\hline $12 / 06 / 2001$ & L'Adige & Informatica Trentina, la Provincia rinvia le nomine \\
\hline $24 / 06 / 2001$ & L'Adige & Informatica Trentina. Ed è il blocco \\
\hline $28 / 06 / 2001$ & L'Adige & Informatica Trentina, spunta Merler \\
\hline $11 / 08 / 2001$ & L'Adige & Informatica Trentina, vertici a tempo determinato \\
\hline $19 / 09 / 2001$ & L'Adige & Informatica Trentina rilancia la sfida al mercato \\
\hline $28 / 09 / 2001$ & L'Adige & Informatica Trentina, troppe occasioni perse \\
\hline $29 / 09 / 2001$ & L'Adige & Informatica, in arrivo le nuove strategie \\
\hline $25 / 10 / 2001$ & L'Adige & Informatica Trentina, nuovi prodotti \\
\hline $31 / 10 / 2001$ & L'Adige & Ritirato il disegno di legge su Informatica Trentina \\
\hline $06 / 11 / 2001$ & L'Adige & Informatica Trentina, nessuna precarietà \\
\hline $08 / 02 / 2002$ & L'Adige & Informatica Trentina, partner prezioso \\
\hline $20 / 04 / 2002$ & L'Adige & Firma digitale nuovo business \\
\hline $07 / 05 / 2002$ & L'Adige & Informatica Trentina, Battistoni si dimette \\
\hline
\end{tabular}


Table 1 (continued)

\begin{tabular}{|c|c|c|}
\hline Date & Newspaper & Title \\
\hline 08/05/2002 & L'Adige & Informatica Trentina, dipendenti preoccupati \\
\hline $09 / 05 / 2002$ & L'Adige & Informatica Trentina, il sindacato chiede una svolta \\
\hline $21 / 05 / 2002$ & L'Adige & Informatica Trentina, Fantoni direttore pro tempore \\
\hline $24 / 05 / 2002$ & L'Adige & Informatica Trentina, si butta sull'e-procurement \\
\hline $11 / 07 / 2002$ & L'Adige & Informatica Trentina, il 40\% Finsiel va in mani locali \\
\hline $11 / 07 / 2002$ & L'Adige & I sindacati, serve una verifica \\
\hline $11 / 07 / 2002$ & L'Adige & Dellai: "l'accordo rafforza la spa" \\
\hline $12 / 07 / 2002$ & L'Adige & Informatica Trentina, Sia pronta ad entrare \\
\hline $12 / 07 / 2002$ & L'Adige & La privatizzazione è possibile \\
\hline $13 / 07 / 2002$ & L'Adige & La quota Informatica Trentina in De Da il prima possibile \\
\hline $16 / 07 / 2002$ & L'Adige & Azionisti di Informatica Trentina, ma autonomi \\
\hline $31 / 07 / 2002$ & L'Adige & La privatizzazione è solo rinviata \\
\hline $02 / 08 / 2002$ & L'Adige & Informatica Trentina, la Cisl polemizza con Dellai \\
\hline 03/08/2002 & L'Adige & Informatica Trentina, pronto il piano \\
\hline 06/08/2002 & L'Adige & Informatica-Unicredit, joint-venture più vicina \\
\hline 28/08/2002 & L'Adige & Informatica Trentina, sì al piano \\
\hline $05 / 09 / 2002$ & L'Adige & Francesca Fantoni a capo di Informatica Trentina \\
\hline $11 / 09 / 2002$ & L'Adige & Seac, verso il no a De Da \\
\hline $21 / 09 / 2002$ & L'Adige & Piano strategico, sindacati favorevoli \\
\hline $26 / 09 / 2002$ & L'Adige & In De Da, Sia vuole esserci \\
\hline $23 / 10 / 2002$ & L'Adige & De Da, anche Informatica Trentina dà il suo gradimento \\
\hline $22 / 11 / 2002$ & L'Adige & Sia, via libera ad Aldebra \\
\hline $14 / 12 / 2002$ & L'Adige & Informatica Trentina, appalti e polemiche \\
\hline $31 / 12 / 2002$ & L'Adige & Informatica Trentina apre l'azionariato ai dipendenti \\
\hline $31 / 12 / 2002$ & L'Adige & Joint venture con Unicredit al via \\
\hline $15 / 01 / 2003$ & L'Adige & Unicredit e Informatica Trentina, parte Unienti \\
\hline $31 / 01 / 2003$ & L'Adige & Vogliamo collaborare con Informatica Trentina \\
\hline $21 / 02 / 2003$ & L'Adige & Aldebra sfrutterà le sinergie del territorio \\
\hline $28 / 02 / 2003$ & L'Adige & Informatica Trentina, via alla rivoluzione \\
\hline $11 / 03 / 2003$ & L'Adige & Uni-It" sarà costituita domani \\
\hline $30 / 04 / 2003$ & L'Adige & Informatica Trentina, il bilancio della svolta \\
\hline $06 / 05 / 2003$ & L'Adige & Informatica Trentina, nuova primavera \\
\hline $24 / 05 / 2003$ & L'Adige & La Provincia centralizza gli acquisti \\
\hline $12 / 07 / 2003$ & L'Adige & $\begin{array}{l}\text { Nuova convenzione con Informatica Trentina, la Provincia } \\
\text { risparmierà } 2 \text { milioni }\end{array}$ \\
\hline $25 / 07 / 2003$ & L'Adige & Ae Bolzano entra in Informatica Trentina \\
\hline $02 / 08 / 2003$ & L'Adige & Ibt flirta con Informatica Trentina \\
\hline $09 / 09 / 2003$ & L'Adige & Informatica Trentina dice sì a Uni-It \\
\hline $30 / 12 / 2003$ & L'Adige & Informatica Trentina, il mercato traina il business \\
\hline $05 / 02 / 2004$ & L'Adige & Informatica Trentina sbarca a Roma \\
\hline $30 / 03 / 2004$ & L'Adige & Uni It, partita l'espansione \\
\hline $07 / 04 / 2004$ & L'Adige & Informatica Trentina, vola l'utile netto \\
\hline
\end{tabular}


Table 1 (continued)

\begin{tabular}{|c|c|c|}
\hline Date & Newspaper & Title \\
\hline $13 / 05 / 2004$ & L'Adige & Informatica Trentina spinge sui dividendi \\
\hline $19 / 10 / 2004$ & L'Adige & Banda larga, regia a Informatica Trentina \\
\hline 28/10/2004 & L'Adige & Informatica Trentina, bene i ricavi \\
\hline $03 / 12 / 2004$ & L'Adige & Intesa per l'operazione It-Dexit \\
\hline 21/12/2004 & L'Adige & Osservatorio sull'informatica \\
\hline $26 / 03 / 2005$ & L'Adige & Banda larga, 15 milioni a Informatica Trentina \\
\hline $30 / 03 / 2005$ & L'Adige & Informatica Trentina, sì ai conti \\
\hline $31 / 03 / 2005$ & L'Adige & Più ricavi ma meno profitti per It \\
\hline $10 / 05 / 2005$ & L'Adige & Informatica Trentina spinge sugli investimenti: $+53 \%$ \\
\hline $17 / 05 / 2005$ & L'Adige & Informatica Trentina e Sap, alleanza per la $\mathrm{Pa}$ \\
\hline $29 / 06 / 2005$ & L'Adige & Intesa difficile tra Informatica Trentina e Tiscover \\
\hline $30 / 07 / 2005$ & L'Adige & Semestrale in crescita per Informatica Trentina \\
\hline $08 / 11 / 2005$ & L'Adige & Informatica Trentina, nel 2005 giro d'affari di 43 milioni \\
\hline 24/12/2005 & L'Adige & Più mercato nel futuro di It \\
\hline $28 / 12 / 2005$ & L’Adige & Informatica Trentina, 1,4 milioni di utile \\
\hline $29 / 12 / 2005$ & L'Adige & Informatica Trentina cresce del $12 \%$ \\
\hline $13 / 04 / 2006$ & L'Adige & Informatica Trentina cresce del $14 \%$ \\
\hline $16 / 05 / 2006$ & L'Adige & Informatica Trentina, il dividendo sale a 1,6 milioni \\
\hline $30 / 07 / 2006$ & L’Adige & Informatica Trentina, a rischio un quarto del volume d'affari \\
\hline 03/08/2006 & L'Adige & Bersani salva Informatica Trentina \\
\hline $22 / 09 / 2006$ & L'Adige & Bersani, informatica in campo. Un documento per modificarla \\
\hline 23/09/2006 & L'Adige & Informatica Trentina, allarme della Rsu \\
\hline $26 / 09 / 2006$ & L'Adige & Bloccata ogni trattativa \\
\hline 27/09/2006 & L'Adige & Informatica Trentina e sindacati, pace su Bersani \\
\hline $09 / 12 / 2006$ & L'Adige & Informatica Trentina, cinque milioni alle imprese locali \\
\hline $13 / 12 / 2006$ & L'Adige & Informatica Trentina, sì al nuovo orario \\
\hline $14 / 12 / 2006$ & L'Adige & Informatica Trentina, la regione sarà azionista \\
\hline $20 / 12 / 2006$ & L'Adige & Informatica Trentina, utile netto a 2,4 milioni \\
\hline
\end{tabular}

O'Dwyer, 2004) to isolate components connected with the main changes which had occurred in the firm.

\subsection{Data analysis}

The analysis of the raw data followed an iterative process of data collection and analysis. First, on the basis of the archival documentation, the authors developed a rich case study comprised a timeline of events and places, and a list of key institutional facts (e.g., laws) shaping the lifespan of the case study firm (Table 2). The documental content analysis was performed to analyse the contextual elements of time and place and their role in the events affecting the firm. 


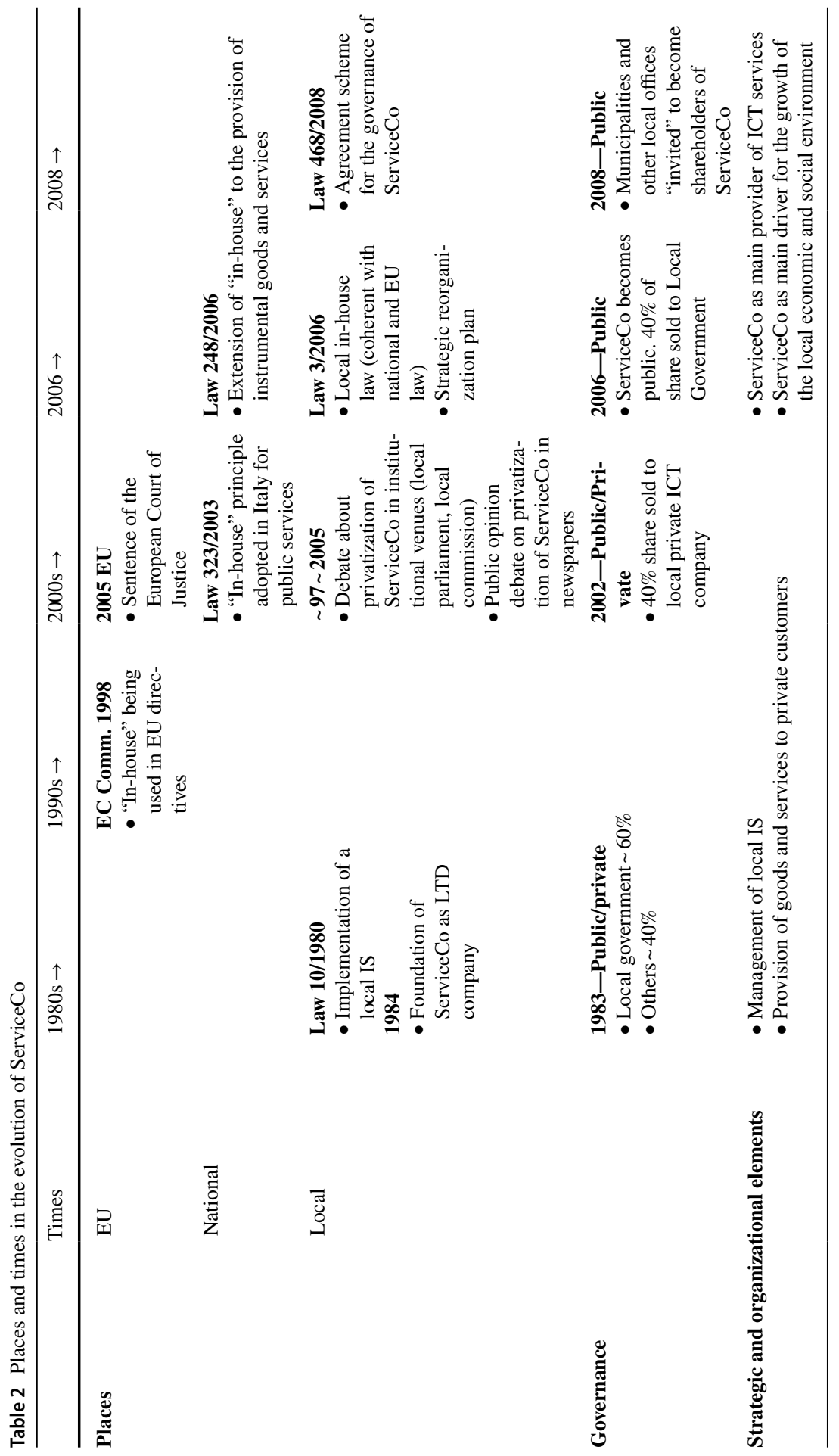




\subsubsection{Place and time notions applied to the case study}

According to the definition of place encompassing the geo-political scenarios in which the field of power develops and shapes the equilibrium of different logics (Lawrence \& Dover, 2015; Mangez \& Liénard, 2015; Dubois, 2014; Bourdieau, 1996), we identified three main places:

- The European Union.

- Italy as a National Institution.

- Local government.

These places are particularly significant when examining how the balance of logics is established in our case study because they are linked hierarchically: decisions and norms taken at the European level shape those at the national and local levels. In the places mentioned above, the equilibrium of logics regulating the case study firm is established during a precise historical time (Suddaby, 2015) related to the development of a form of Neo-liberalism within the EU boundaries (Ban, 2016; Pänke, 2019; Raik, 2016).

Consequently, time has to be considered as the temporal framework created by the norms resulting from historical evolving conditions that regulate the existence of the case study firm. The information concerning the case study firm was then enriched with the insights taken from the interviews and then used to better identify and clarify the most critical factors and the logics that shaped changes in its strategies, governance and organizational makeup over time.

\section{The case study firm}

ServiceCo is a firm that provides Information and Communication Technology (ICT) services such as development, implementation and management of information systems, data transmission applications and various additional ICT services.

ServiceCo operates in a place characterized by particular features; it is located in an autonomous Italian province, which for historical, political and geographical reasons had obtained special autonomy status some 60 years ago. This status allowed the region to preserve local traditions and create a strong sense of affiliation and community. The difficult geographical morphology of the land is dominated by high mountains that form an environment where people share a deep sense of community. The difficulties in living conditions had created common boundaries and emotional connections which were the building blocks of a strong local community logic (Thornton et al., 2012). The sense of community and solidarity dominated and permeated the local culture by creating common values and ideologies. Nowadays, this sense of community is being fostered by the local government which has special legislative and executive competences in health, education, welfare, the economy, and transportation.

In the 1980s, the local autonomous government decided to build a proprietary IT infrastructure (Fig. 1). Together with other public national shareholders, the local 


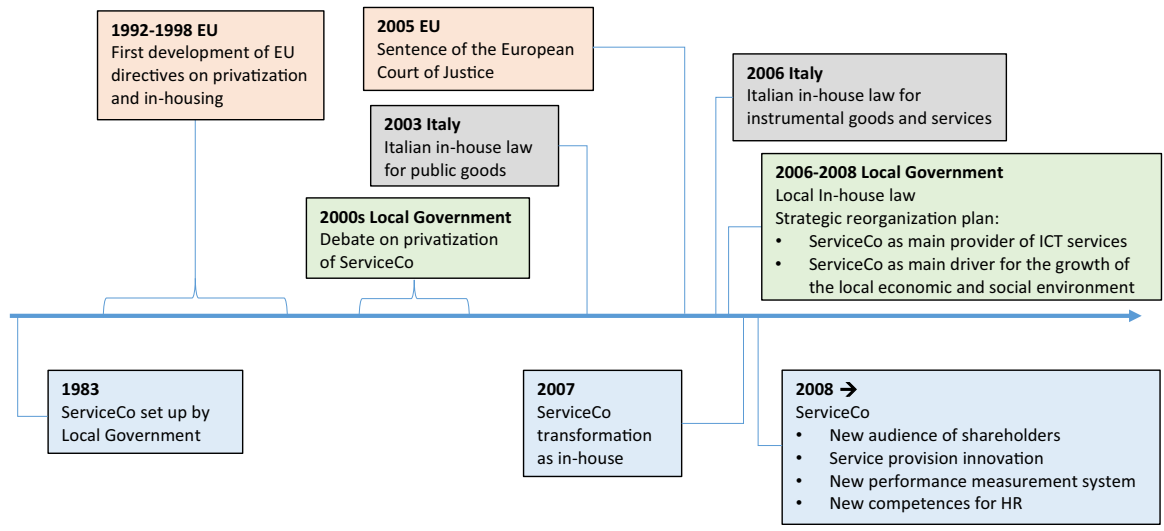

Fig. 1 Places and times cornerstones in the evolution of ServiceCo

government founded the company as a joint-stock entity. The shareholder structure was roughly $60 \%$ local government and $40 \%$ other shareholders. The initial aim of this company was to design, implement and manage the electronic information system of the local government, but in accordance with the local law (10/1980), the firm could also offer its services to private and public third parties. This is clearly set out in the business objective as described in the company's statute:

The company specialises in the industrial activity related to:

(a) The management of the electronic information system and planning, development and implementation of other interventions delivered by the local government (...)

(b) The design, implementation and operational management of other information systems for subjects other than those referred to in Article 1 of the provincial law... (translated excerpt from the Italian Statute, 1983, Article 4)

From these objectives, it is possible to infer that the firm was set up as a hybrid organization pursuing both a social goal (developing an IT system for the local institutions and community) and a market goal (offering IT services to the broader market). Indeed, while the specific goal of the company was that of creating and managing the IT infrastructure of the local government, the company operated mainly in a competitive market:

But, in the beginning, no one prevented ServiceCo from developing business outside the provincial borders, offering its IT products to other administrations as well. It was probably in this spirit that a share of the capital of ServiceCo was attributed to a national public-owned company, the ideal partner in the 1980s, to compete within a larger market .... (Translation, Benati, 2000)

Until 2020 the firm's governance, strategy, service provision model and organizational setting had not changed radically; the turnover from its private customers was still around $28 \%$ of the total turnover. However, at the beginning of the new 
millennium, the European and national reforms together with the public debate about the single market for services within the European Union generated pressure on the institutional, strategic and organizational dimensions of ServiceCo (Benati, 2001).

As described in the following sections, the changes that determined a new equilibrium of logics within the company can be interpreted as the result of the combination of historical time conditions (Ban, 2016; Pänke, 2019; Raik, 2016) able to generate new power equilibriums (Bourdieau, 1996) at various geo-political levels. The ensuing story can be seen as two chronologically successive periods, with 2006 a milestone. Within the first period (Sect. 4.1), we discuss the triggers of change at different places while in the second (Sect. 4.2), we investigate how the triggers of change propelled ServiceCo along a trajectory which modified its equilibrium and caused an adaptation to the pressures of institutional logics.

\subsection{Place and time at European Union (EU) and national levels}

\subsubsection{Late 1990s: the European legislation influencing the place of European Countries}

The organization under investigation is located within an influential place, namely the European Union (EU). This is the most influential place in which the organization operates. The EU exerts influence over the other geopolitical 'places' i.e., the other institutional levels such as states, regions, etc. in the European area.

Since the 1990s EU legislation has been particularly oriented to guarantee the free movement of goods, capital, services and labour within the EU towards the socalled European single market by adopting a clear orientation toward "transnational neoliberal socioeconomic order" (Cafruny and Ryner, 2003, p. 5).

Such orientation is laid out in Directive 92/50/EEC (Council Directive, 1992) where the European Union began to define the principles of a European competitive environment as a way to reduce monopolistic positions of both private and publicowned companies. For example, in a 1995 document, the European Commission clearly addresses the need to develop competitive environments while preserving certain types of public services:

The removal of barriers to trade requires the establishment and enforcement of a new set of transparent rules to regulate competition. In the absence of such rules, the desired optimal allocation of resources would be frustrated by anti-competitive behaviour. Competition rules need to regulate both company and state behaviour in four main areas: (...) state monopolies of a commercial character, public undertakings and undertakings with special or exclusive rights also present a risk for free and open competition. There is deliberate creation of economic rents for certain players based on the assumption that the benefit is used for delivering public services or will accrue to the state as revenue. Whilst this is basically unobjectionable, it is a delicate task to constrain the market distortion to what is strictly necessary 
in the general interest, for instance with a view to the provision of public services in remote areas. (Commission of the European Communities, 1995, page 15)

Later in the 1990s, the European legislation aimed at creating the legal basis for a clearer single European market characterized by its own form of neoliberalist ideas that could encompass the different equilibriums between the state and the market logic in existence in the different countries in the Union (Ban, 2016; Pänke, 2019; Raik, 2016).

Two main lines of reforms can be identified: the first concerns the liberalization of the provision of public services. Earlier directives were aimed at specific sectors such as telecommunications, energy, rail transport, waste and postal services and required all EU members states to commit to a deregulation plan to open up public networks to private operators. This brought about a period of privatization of publicly owned firms operating in the abovementioned industries (Monteduro, 2014). This deregulation eventually produced the Services in the Internal Market Directive, 2006/123/EC, the so-called Bolkestein Directive" (Market Directive, 2006).

Together with these directives, the second line of reforms aimed at regulating the legal, business and operational limits of firms whose ownership remained in public hands. Within this second stream, it is possible to identify 'in-house providing' as one of the main reforms of publicly owned firms in Europe (Comba and Treumer, 2010). The goal of the regulator was to define the limits within which public authorities may award public services to specific companies without holding a public tender. In 1998, the European commission officially introduced the concept of in-house:

... the Commission proposes to clarify the following particular topics in an interpretative document: (...) — “in-house" contracts, i.e., contracts awarded within the public administration, for example between a central and a local administration or between an administration and a company wholly owned by

it. (Commission of the European Communities 1998, subnote 10, page 10)

The in-house principle allows public institutions to entrust a specific firm with the provision of services and goods by derogating from the obligation to apply public tendering. Since this principle in balancing between state and market could violate the principles of fair competition, the European legislator stated that a public authority might use the in-house principle only when the authority exerts predominant control and power over the firm: in this case, the firm is considered part of the public authority. This approach was finally adopted in Italy in 2003. From an institutional logics point of view, these reforms thus created the institutional space for two main logics i.e., that of the market and that of the state (Table 3 ).

This first set of laws did not influence the identity and strategic scope of ServiceCo. Indeed, the focus of such reforms was the provision of public services in electricity, emergency services, public transportation, waste management and water supply (Muraro, 2008). Only in 2005 were the in-house providing principles extended to the type of services provided by ServiceCo (Clarke and Pitelis, 2005). 


\subsubsection{Early 2000s: a time of regulation ambiguity within the EU place}

The application of the first hybrid neoliberalist EU norms (Ban, 2016; Pänke, 2019; Raik, 2016) resulting in an unclearly defined equilibrium within the field of power (Mangez \& Liénard, 2015; Dubois, 2014; Bourdieu, 1996). This generated a period of ambiguity regarding the governance of publicly owned firms at the turn of 2000 (Cintioli, 2014). In 1999, the European Court of Justice had already introduced a set of further principles for the public procurement of goods and services by public authorities (C-107/98). This period saw the spread of a general public debate about the concept of services of general economic interest (thereafter SGEI ${ }^{1}$ ): the discussion also affected the debate about the privatization of publicly owned firms (Dawson \& Sykes, 2019; Granqvist \& Gustafsson, 2016; Janssen, 2014; Wehlander, 2016).

This ambiguity can also be found in the local place where ServiceCo operates. Even if not directly affected by the recently adopted directives, the public debate regarding the privatization/in-housing of ServiceCo was indeed reflected at a local level: a heated debate was sparked within institutions about whether or not to privatise the firms owned by the local government, including ServiceCo (Local Benati, 2000; Bovis, 2012; Calliari, 2010; Caretto, 2002; Cintioli, 2014; Local Council, 2000, 2001; Pancia, 2001; Paris, 2000; Reggi \& Ricci, 2014; Ursi, 2005).

An analysis of the 153 articles from 1997 to 2006 (Table 1) shows the following results: 54 focused on the idea, supported by the local government, of privatizing ServiceCo; only 5 articles clearly described the reasons for a ' $n o$ ' to privatization.

A further 21 articles (1997-2004) dealt with two other very delicate issues: the monopolistic role of ServiceCo in providing ICT services to the province and the need to increase the turnover of private companies (at the time about $30 \%$ of the total revenue).

The public debate about in-housing started raising again over the period with as many as 8 articles in the last 2 years alone.

At European, national and local level, the debate about privatization/in-housing did not reach a final point until the issue of EU sentences in 2005: the debate concluded with two sentences from the European Court of Justice (Dawson \& Sykes, 2019). In Sentences no. C-26/03 and no. C-458/03, the Court issued a final interpretation of what should be considered in-house providing and how to award public services. In these documents, the Court clearly defined the span and limits of public tender, the in-house providing and the related awarding procedures.

These sentences can also be read as the triggers for a new wave of in-house laws that focused better on the legal limits of the provision of public services as described below.

\subsubsection{6: National places. Legislation influencing the place-'Italy'}

While the first in-house Italian legislation applied only to public services, the European Court sentence generated the need to create specific national laws in each single state (Dawson \& Sykes, 2019; Granqvist \& Gustafsson, 2016; Janssen, 2014). This culminated in Italian Law 248/2006 where the in-house principle

\footnotetext{
1 SGEIs are economic activities that public authorities identify as being of particular importance to citizens and that would not be available if there were no public intervention.
} 


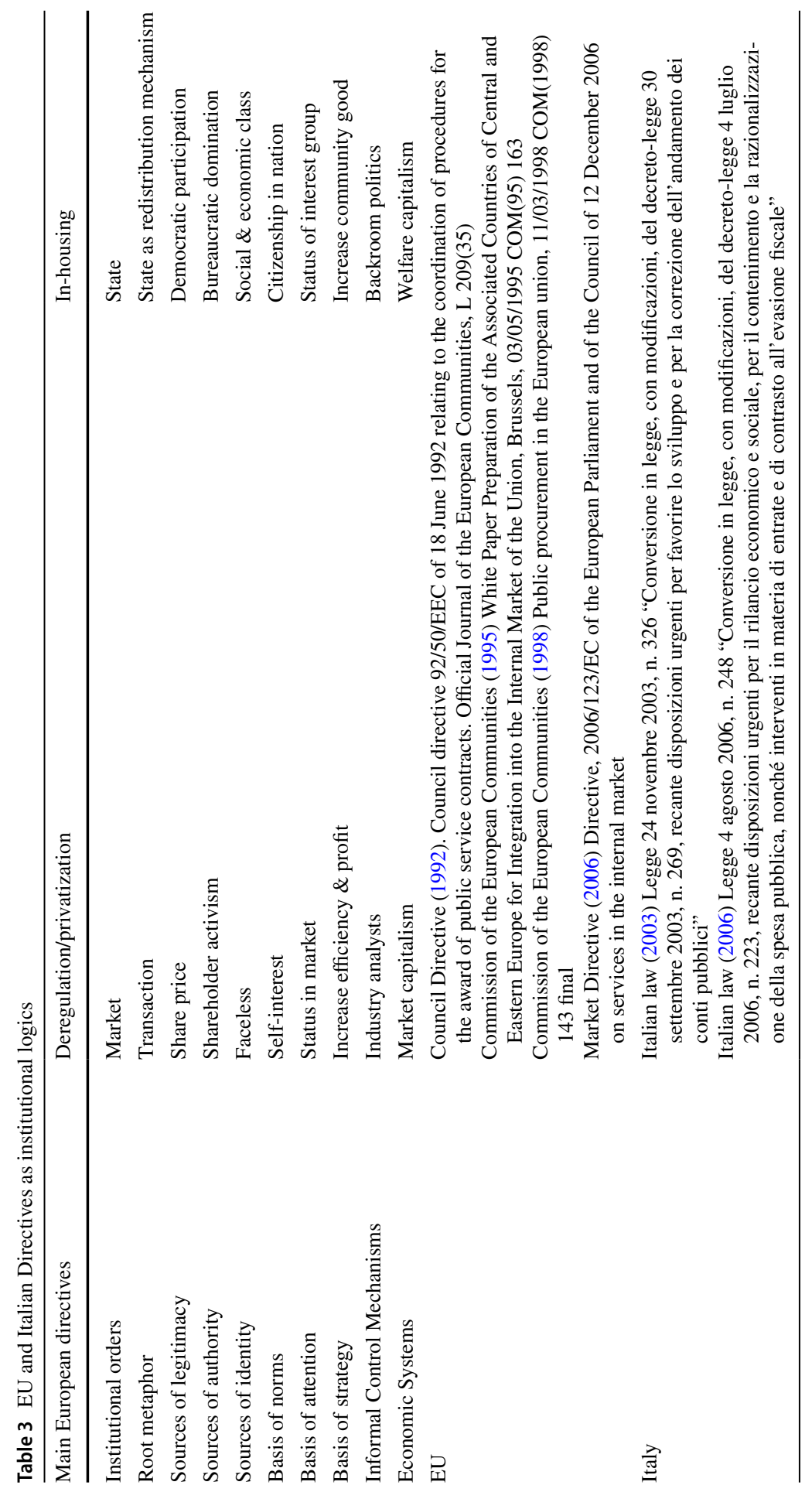


was extended from the provision of public services to the provision of instrumental goods and services:

In order to avoid alterations or distortions of competition and the market and to ensure the equality of operators, companies with full public or mixed capital, established or participated in by the regional and local public administrations for the production of goods and services instrumental to the activity of such institutions must operate exclusively with the constituent or participant or entrusting bodies; they cannot perform services in favour of other public or private subjects, neither in direct assignment nor with tender, and they cannot participate in other companies or entities. (Translation Italian Law 2006, art. 13)

In short, Law 248 states that in order to reduce any unfair competition in-house firms may provide instrumental goods and services only to their shareholders. In terms of time and place, this latter legislation was a major change for ServiceCo as it affected those fully or partly publicly-owned firms that provide instrumental goods and services (Fig. 1).

\subsubsection{6: Legislation translated at local level by Local Government}

In the wake of the national legislative changes and in the light of the changes in the Italian in-house legislation (e.g., Law 248/2006), the local government adopted strategic decisions to apply these overarching rules while preserving the local autonomy (Table 2). The "local flavor" of neoliberalism (Ban, 2016) became more evident as the geo-political level was much more focused. In the case under investigation, the institutional autonomy granted to the local government and the willingness to preserve the culture of the local community can be seen in the decisions taken in 2006 when it was clear that ServiceCo should have, by law, changed its strategy and governance. The preservation of the values of the local community, as embedded in the community logic, were also embedded in the strategies and laws issued by the local government (Table 4). The local government planned and adopted a broad strategic 'reorganization plan' for the network of its firms (Fig. 1). The goal of such reforms is well represented in the provincial law under the article entitled Rules on the governance of the local autonomy:

This law is aimed at reassuring the populations established in the territory and the linguistic groups in which they recognize themselves, through the process of reorganization of the provincial and local institutions inspired by the principles of subsidiarity, differentiation and adequacy. (Translation Local Law, 2006) 


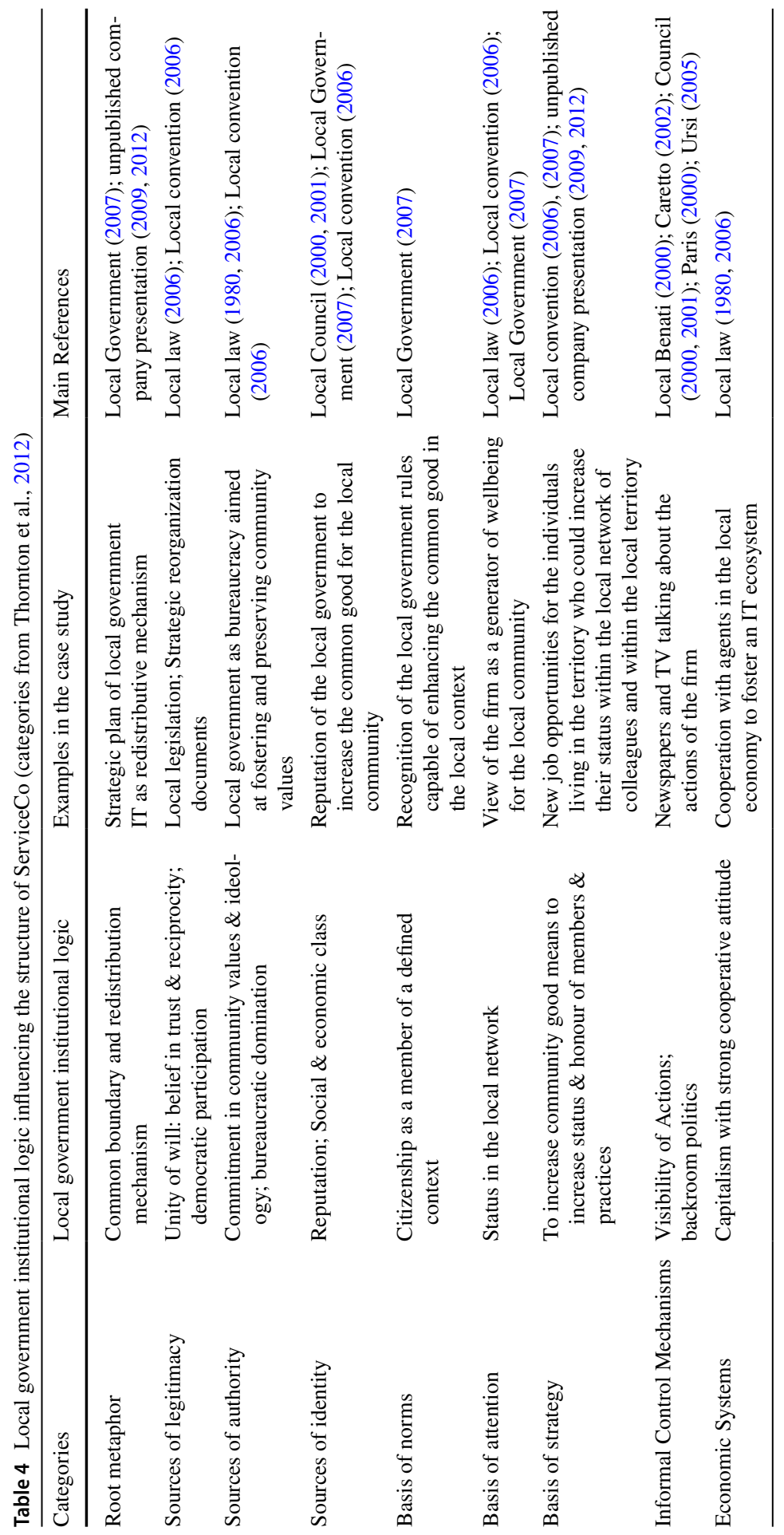


Such new logic eventually brought many strategic, organizational and governance changes within ServiceCo.

\subsection{The interaction of 'place' and 'time': changes at organizational level}

2006 was a cornerstone year in the equilibrium between the competing forces governing ServiceCo. While previously the debate regarding privatization/in-housing did not bring visible changes in terms of strategy, governance and organizational setting in ServiceCo, such changes became more visible after the directives, sentences and laws clarified the role of firms owned by public institutions.

The institutional logics affecting or governing the existence of ServiceCo were deeply intertwined. ServiceCo development and evolution had been oriented over a long period of time by 'places' (the EU and Italian State) that, due to the influence of neoliberalism, remained detached from the culture of community in which ServiceCo operated. While the new European and Italian jurisdiction procured a new equilibrium of powers (Mangez \& Liénard, 2015; Dubois, 2014; Bourdieu, 1996) by shaping a new form of neoliberalism (Ban, 2016), ServiceCo was forced to change governance and business span. The logic of the local government became dominant and a powerful instrument of organizational change (Table 4). Indeed, following the European and Italian recommendations regarding in-house firms, the reorganization plan issued by the local government played a central role in the changes affecting ServiceCo. These changes and innovations stemmed from the new balance of institutional logics and the structuration of the governance system (Barley \& Tolbert, 1997; Quattrone, 2015). From the official documents and reports of the local government describing the reorganization plan, it is possible to deduce two principles which affected the strategic, governance, and organizational setting of ServiceCo (Local Government 2007):

(1) The first principle stated that, in line with in-house European and national recommendations (customer base restricted to the shareholders only), ServiceCo would become the main strategic provider of ICT services for the local government and all other local institutions. This meant that all the local institutions would become shareholders in the firm.

(2) The second principle stated that since ServiceCo had become a publicly owned company, its governance strategy should change by pursuing social aims instead of merely financial goals.

As a result, ServiceCo would become the main strategic driver fostering the growth of the local economic and social environment by creating and fostering a local industry of ICT firms.

Such decisions have to be understood in the context or the 'place' in which the organization operates. These decisions were grounded in the community institutional logic which pervaded the local environment: ServiceCo was founded in a region where supporting the local economy, local networks, and acting for the 
wellbeing of the community was - and still is - the basis of the pervasive community logic and culture.

The authors identified the structuration of four main changes in ServiceCo (Strategic plan, 2008; Local Government, 2007, 2008, 2009; Local Convention, 2006; unpublished company presentation, 2009, 2012). These changes are described in the following sections.

\subsubsection{Legal status, customer base and governance model}

By the end of 2006, ServiceCo was commended by law to become a fully publicly owned firm and to adhere to the in-house norms: the structure of the firm needed to adapt to the constraints envisaged by EU, national and local legislation for the provision of services by public administrations. It would provide services only to its shareholders and, thus, the shareholders would also become its customers.

This legal obligation was coupled with the strategic reorganization plan to make ServiceCo the main strategic provider of ICT services for the local government and all other local institutions. The local government first acquired $40 \%$ of privately held shares, and then advised all the local institutions, municipalities and other authorities to become shareholders in ServiceCo; these authorities included local municipalities, libraries, schools, the university, land registry offices, hospitals and clinics, and tourist offices. More than one hundred offices and institutions became potential customers and ServiceCo was required to progressively terminate its contracts with private clients. Since 2006, this approach has been outlined in a new business objective in the statute:

(Corporate purpose): The Company, with entirely public capital, is the instrument of the local Administration system for the design, development, maintenance and operation of the electronic information system (...), for the benefit of the Administrations themselves and of the other bodies and entities of the system, in compliance with the current regulations. (Translated excerpt from the Statute, 2006, Article 4)

The shareholding structure contained 185 public shareholders in 2018, all of them part of the local government infrastructure.

Following the change of the legislation and adoption of the reorganization plan in 2006, the mission of ServiceCo underwent a profound transformation to achieve social aims. The process of change took place by virtue of the application of laws issued by European, Italian and local institutions. The legal obligations issued at different levels were intertwined with the local goals to help and improve the territory: the reorganization plan transformed the firm into a strategic driver for the economic and social growth of the local community. 


\subsubsection{Service provision model}

The local government tried to achieve the goals of the strategic reorganization plan by structuring an innovative service provision model (unpublished company presentation, 2009, 2012). First, a series of strategic activities were undertaken to create and foster a strong local ICT industry. This was done by setting up networking opportunities for the local ICT firms e.g., conferences on ICT topics and training for the local firms. These meetings also allowed the firms to get to know each other and eventually build business relationships (Fig. 2).

Secondly, as shown in the financial statements, the firm began downsizing its own operations and outsourcing activities as a means to involve local firms in the provision of ICT goods and services. This approach developed further into a support for collaborative networks of firms working on IT projects. Thus, ServiceCo became a facilitator for the ICT needs of the new customer base (local government and new public shareholders) and the private companies providing ICT services. This can be considered an enormous innovation in terms of the governance and management of the firm as it moved from being a centralized vertical organization providing ICT services to a network-based organization capable of facilitating the interaction of supply and demand of ICT goods and services while fostering the local economic and social environment.

The intent of positively affecting the local wellbeing of the community and increasing the number of the people whose status might be improved by ServiceCo outsourcing further highlights the effect of the local government institutional order. The resulting structured change process and new equilibrium involved recognition of the community logic, a fundamental component of the local context.
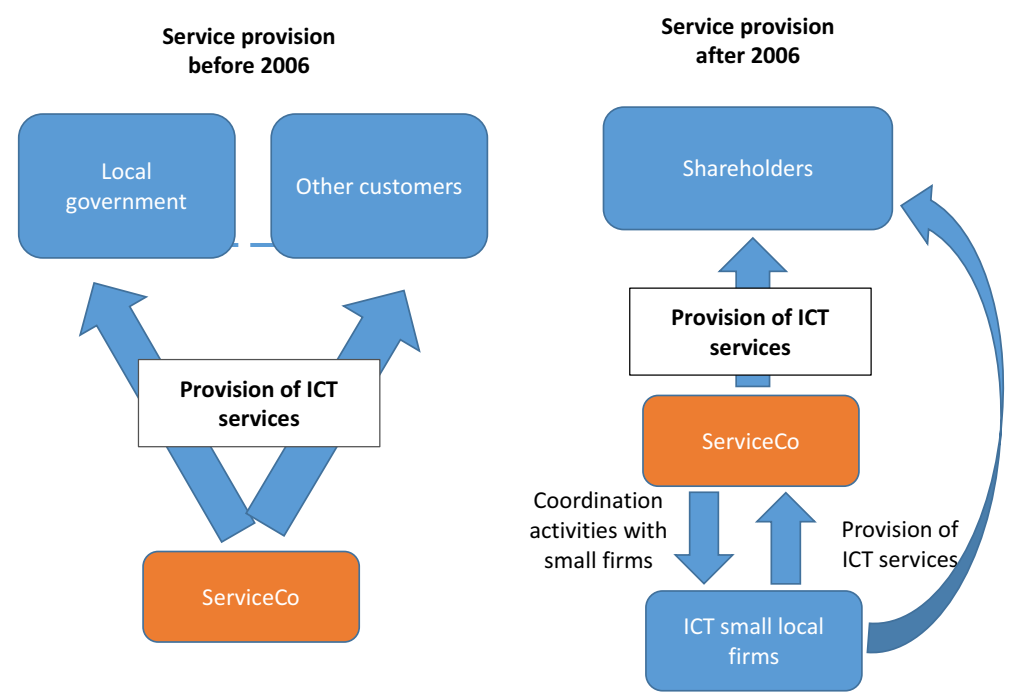

Fig. 2 Service provision model of ServiceCo 


\subsubsection{New roles and competences of IT project managers}

It is important to note that the firm, as a conduit between the demand and supply of ICT services, altered the role of its IT experts and generated the need to develop new skills and competences within the firm. As the strategy of the firm moved 'from creating inside to selling outside' (Interviewee, 1), the role of the IT experts changed from being managers of internally developed IT projects (managing other IT personnel) to managers of collaborative projects with different agents (interacting with other organizations). As such, the role of the managers was no longer that of technical experts but that of boundary spanners in collaborative networks of heterogeneous people and organizations (Levina \& Vaast, 2005). This change of role can also be seen in the change of managerial competencies as Interviewee 1 said, “... over the following years (after 2006) ICT project managers moved from being IT experts to legal experts."

Because of such changes, the status of the individuals involved in ServiceCo provision was modified in terms of professional progress and competencies, thus determining a new basis for a future strategy and the development of the local context.

\subsubsection{Culture of measurement and management accounting system}

One of the main outcomes of the new equilibrium governing ServiceCo activities is the construction of the management accounting system (MAS) which reports on the economic and social sustainability of the firm on the basis of the goals expressed by the local government.

Thanks to the growing public debate on the accountability of publicly owned firms and the discussion regarding the privatization of ServiceCo in early 2000s, the management of the firm decided to investigate and eventually to introduce a MAS. The goal was to make the firm more accountable to a larger number of stakeholders by providing a clearer view of the social and economic impact of the firm on the local environment.

From 2003, managers of both the local government and ServiceCo together with the academic consultants (see Sect. 3.1.3) discussed the opportunity of creating a report which became a Sustainability Balanced Scorecard (ServiceCo, 2007, 2008, 2009, 2010, 2011; ServiceCo Balanced Scorecard, 2011, 2012, 2013; ServiceCo Strategic and Industrial plan, 2008). This choice was the result of a series of roundtables involving all the parties (Ponte et al. 2017).

After a period of experimentation, the SBSC was adopted in 2005: the scorecard report was also attached to the financial statements and made public in 2010 .

The new performance management system consisted of up to fifty indexes measuring phenomena as diverse as the percentage of externalization of product development, the benefit per worker, taxes paid to the shareholders and purchases from local firms. Key indexes were also "tailored to describe the strong commitment toward the local community attributed to the new ServiceCo structure" (Interviewee 2).

The report became a new strategic measurement tool to develop specific indexes (financial and non-financial), where the most important aimed at measuring the growth in jobs and community wellbeing. Among others, a particularly 
interesting critical success factor was that "the ability of ServiceCo to create new job opportunities for the individuals living in the territory became one of the main goals of the new organizational mission" (Interviewee 2).

The content analysis of the social and environmental reports also showed an evolution in terms of the results of the new ratios and measurements developed. When explaining the role of these ratios and measurements, an interviewee stated that:

In this particular geographical area, where traditionally the community exercises a very strong influence, it is more important to account for ServiceCo's ability to guarantee careers and jobs connected to the growth of the local territory than just financial performance. (Interviewee 1).

This statement is especially true when considering the hybrid nature of ServiceCo but the geographical context in which this organization operates cannot be overlooked since the sense of community and membership dominate people's culture and values. In particular, the accountability system was adopted to provide evidence of the positive impact of the new hybrid organization on the local environment since ServiceCo had to be perceived as being able to generate wellbeing for the community. As explained by Interviewee 1:

The person who decided to adopt this measurement system was aware of its importance in terms of the visibility of the organizational actions, the reputation of the organization itself and its members, but also in terms of belief in the organizational alignment with the wellbeing of the local community (Interviewee 1).

An interesting result of the adoption of the MAS was the growth of a new "culture of measurement" (Interviewee 2) within the firm. The topic of culture is particularly important when a new equilibrium of power needs to be built i.e., the statements of the reorganization plan because it enables power groups to operate under specific cultural rules (Bourdieau, 1996). The new culture of measurement (Busco \& Scapens, 2011; Ax and Grave, 2017), also referable to an outcomeorientation culture, brought a new wave of reports aimed at better investigating the nearby environment and at empowering the new organizational community logic by supporting, orienting and legitimating new manager decision-making processes in the new service provision model (Cinquini \& Tenucci, 2010; Henri, 2006). Among others, four reports clearly show the aim of carrying out preliminary investigation of the different needs and criticalities of the new customer base (Sect. 4.2.1) with the goal of supporting the new service provision model (Sect. 4.2.2) while progressively transforming the role of engineers (Sect. 4.2.3):

- Recognition and analysis of the software installed by the municipalities' stakeholders of the firm (2011). 
- Recognition and analysis of the digital and vocational skills required by local ICT companies (2011).

- Database of the competences of local ICT companies (2012).

- Detection and analysis of the perception of the usefulness of the territorial collaboration system (2013).

Such findings are clearly linked with the strategic reorganization plan and with the need to become more accountable to the shareholders/clients. In conclusion, such regulator practices were recognized to have a strategical relevance in driving the performance of the firm and in satisfying clients (Baird et al., 2004, 2007, 2018).

\section{Discussion}

The ServiceCo case study shows the evolution of the company as a result of challenging and reconciling institutional logics (Langley et al., 2013). The final configuration of the company is the result of the geo-political places influencing the organization's choices (Lawrence \& Dover, 2015) and the equilibrium of power established over time (Mangez \& Liénard, 2015; Dubois, 2014; Bourdieau, 1996; Suddaby, 2015). At the macro level of the EU and national regions, strong debates and discussions generated a negotiation process regarding privatization versus the public provision of goods and services (Dawson \& Sykes, 2019; Granqvist \& Gustafsson, 2016) by delineating over time a new EU form of neoliberalism (Ban, 2016; Pänke, 2019; Raik, 2016) that translated into a normative effort for regulating inhouse activities.

In examining this case study, it is important to remember that the local government acted not only as an institutional directive capable of influencing organizational behaviour but as an institutional entrepreneur (Thornton et al. 2012) whose decisions were deeply influenced by the place and the historical timeframe (Suddaby, 2010, 2015). In particular, the historical time (Suddabby 2015) in which the changes took place was influenced by European and Italian legislation and the local 'place' was dominated by the community logic embedded in the local government actions and decisions.

After 2006, by means of its reorganizational plan the local government, took the opportunity offered by the EU and national laws to establish a new equilibrium regarding company strategic, governance and organizational settings. This new balance depends on the role of the State acting at different levels. The local government in the autonomous region in which ServiceCo operates represents the State, but it encompasses the specificity and "local flavors" of the place (Ban, 2016). At organizational level the strategic, organizational and governance elements were structured in accordance with the reorganizational plan issued by the State at local level and influenced by the peculiar place in which ServiceCo operates. The equilibrium of power established over time at local level is particularly influential (Mangez \& Liénard, 2015; Dubois, 2014; Bourdieau, 1996) in a region where the logic of community dominates culturally and historically. The institutional logic (Thornton et al., 2012) of the local government empowered a plan aimed at enhancing the wellbeing 
of the community in a region where a tendency to solidarity is vita, began to modify the previous strategy and organizational setting, and to structure new procedures and operations (Table 4); for example, the structuration of a new system of accountability to measure the social impact on the local community because a major concern for the re-shaped ServiceCo was to increase the job and career opportunities for the local community by constructing new professional paths measurable within the accountability system. The new management accounting tool adopted indeed played a critical role in shaping a new cultural approach (Busco \& Scapens, 2011; Ax and Grave, 2017) at organizational field level by supporting and legitimating a different, new management decision-making process coherent with the community logic. This concern was also pursued by restructuring the service business model from a vertical to a network-style model. The result of the process was an organization governed by the same logics as the local government which had planned changes and innovation in coherence with the nature of its institutional order (Barley \& Tolbert, 1997). The strategy of the firm assumed a different prominence because it shifted from the logic of increasing efficiency and maximizing financial results to the logic of a common good for the community and the good (status) of the individuals who lived therein. In the initial stages of ServiceCo activity, the institutional order of the market, coherent with the dominating neoliberalist approach of that historical period, had been dominant and the privatization of the firm had been sought. Nonetheless, the institutional logics of the local government in a hanged historical framework more inclined to less orthodox forms of neoliberalism prompted a change process that eventually shaped the strategy undertaken by the local government, namely to satisfy community needs. The entire organization was thus modified in accordance with the new root metaphors which transformed ServiceCo into an entity to pursue the common good within common boundaries.

As a result, the entire organization was affected by a series of innovations aimed at re-designing the organizational actions in favour of the logic of the wellbeing of the community and the local individuals. This logic was reinforced by new tools aimed at empowering these individuals. Thus, the community logic expressed by the local government displayed a procedural nature because it induced a structuration of new strategies, organization and governance designed according to the exigencies of the owner.

\section{Conclusion}

This research contributes to the investigation of how different demands from different geo-political places (Lawrence \& Dover, 2015) influence organizations during a historical timeframe (Suddaby, 2015) thus causing the structuration of a new type of organization. In the literature, the innovations driven by changes in the logics governing hybrid organizations are not new and often studied in relation to the particular tools used for shaping the change (Busco et al., 2015, 2017). The case of ServiceCo, however, shows how the context (place and time) is a key issue for understanding the structuration of a new organization governed by a locally dominant logic (Thornton et al., 2012). 
In the case study, the strategies originated in a specific historical period (Suddaby et al., 2015) in which the equilibrium of power established in the EU geo-political place (Mangez \& Liénard, 2015; Dubois, 2014; Bourdieau, 1996) enabled the local government to adopt a reorganization plan. The new equilibrium of powers and consequent logics, acting at organizational level, brought about innovations with the conscious intent to positively influence the wellbeing of the local community.

This work contributes to the literature that studies the links and interconnections between the pressures exercised by different places and related logics (Thornton et al., 2012), and the structuration of a new strategic, organizational and governance system in a given firm. In particular, the paper shows that the place and time are able to generate a new equilibrium of power (Mangez \& Liénard, 2015; Dubois, 2014; Bourdieau, 1996) that at organizational level can translate into a new (dominant) logic: in the examined case, this was the community logic expressed by the local government which encompasses the feature of the place where the organization is located. Thus, the paper explains in terms of place and time the mechanisms and structures that trigger the generation of a locally dominant institutional logic (Suddaby, 2010, 2015; Ebrahim et al., 2014; Mersland and Strom, 2010). The new dominant logic owns an "endogenous dynamism" (Quattrone, 2015) because it requires the structuration of a series of innovations. In particular, the typology of hybridity, resulting from the transformation of ServiceCo in 2006, structured changes in terms of legal makeup, new customer base and governance, new management accounting system, innovative service provision model and new competencies. An equilibrium where the institutional logic of the local government became dominant produced an organizational structure capable of re-shaping the entire business: in the context under investigation, the equilibrium demonstrated robust features of mutuality and cooperation. Furthermore, in order to establish the change at organizational field level a key role was played by the new managerial accounting tool that was able to modify the organizational culture (Busco \& Scapens, 2011) by shaping and legitimating managerial decisions geared to support the new dominant logic (Henri, 2006), clearly apparent from the developed managerial accounting tool aimed at investigating the new customers needs, the availability of competences and the resources of the local IT ecosystems, the needs in terms of human resources and the broader perception of the new service provision model.

Coherently with other empirical research which studies the connection between strategies, culture and management accounting systems (Ax \& Greve, 2017; Baird et al., 2004, 2007, 2018; Zhang et al., 2015), this work suggests that management accounting systems are able to drive cultural organizational changes.

In short, this study contributes to the literature on institutional logics by illustrating how the competing forces in this realm (Pache \& Santos, 2013; Ramus et al., 2017) are capable of enhancing a process of structuration of a series of changes in favour of a dominant institutional logic (Thornton et al., 2012) based on the local context (Suddaby, 2010, 2015). Furthermore, it supports the exigency of studying the logic as the result of a specific context defined in terms of 'place' and 'time' (Quattrone, 2015). In particular, this paper contributes to previous literature by proposing an understanding of the 'place' in terms of geo-political levels where during 'time', intended as its historical development, new balances of power occur 
(Lawrence \& Dover, 2015; Suddaby, 2015; Mangez \& Liénard, 2015; Dubois, 2014; Bourdieau, 1996). The study also aligns with Busco et al. (2017) and Teixeira et al. (2017) in illustrating how management accounting innovation in a hybrid context can be obtained by changing logics and how management accounting itself by creating a new culture (Ax and Grave, 2017) can support renewed dominant logics.

This study also contributes to highlighting how the building blocks of the new institutional order are the results of the contexts, and to exploring the procedural nature of these building blocks.

In addition, the paper contributes to merge institutional logic studies and the perspective of Bourdieusian field theories.

Finally, this research may have implications for managers operating within organizations that are experiencing revolutionary changes at organizational level because it can produce awareness regarding why such changes occur and how the new organizational logic and culture can be assimilated, supported and legitimated.

To conclude, this research is limited to the study of a single organization but it could be extended to other similar organizations which have been affected by the state logic when applying the in-house law in order to show how the context can influence organizational changes. Further research could investigate more specifically the role of 'place', or context, in generating different types of structures and innovations under the institutional logic perspective. In particular, further research could complement our study through other investigations on how different historical timeframes and local peculiarities have enhanced the understanding of neoliberal instances which resulted in local flavours able to strongly influence organizational structures.

Funding Open access funding provided by Università degli Studi di Trento within the CRUI-CARE Agreement.

Open Access This article is licensed under a Creative Commons Attribution 4.0 International License, which permits use, sharing, adaptation, distribution and reproduction in any medium or format, as long as you give appropriate credit to the original author(s) and the source, provide a link to the Creative Commons licence, and indicate if changes were made. The images or other third party material in this article are included in the article's Creative Commons licence, unless indicated otherwise in a credit line to the material. If material is not included in the article's Creative Commons licence and your intended use is not permitted by statutory regulation or exceeds the permitted use, you will need to obtain permission directly from the copyright holder. To view a copy of this licence, visit http://creativecommons.org/licen ses/by/4.0/.

\section{References}

Ahrens, T., \& Chapman, C. (2007). Management accounting as practice. Accounting, Organizations and Society, 32, 1-27

Ax, C., \& Greve, J. (2017). Adoption of management accounting innovations: Organizational culture compatibility and perceived outcomes. Management Accounting Research, 34, 59-74

Bagnoli, L., \& Megali, C. (2011). Measuring performance in social enterprises. Nonprofit and Voluntary Sector Quarterly, 40(1), 149-165 
Baird, K., Harrison, G., \& Reeve, R. (2004). Adoption of activity management practices: A note on the extent of adoption and the influence of organizational and cultural factors. Management Accounting Research, 15(4), 383-399

Baird, K., Harrison, G., \& Reeve, R. (2007). Success of activity management practices: The influence of organizational and cultural factors. Accounting \& Finance, 47(1), 47-67

Baird, K., Su, S., \& Tung, A. (2018). Organizational culture and environmental activity management. Business Strategy and the Environment, 27(3), 403-414

Ban, C. (2016). Ruling ideas: How global neoliberalism goes local. Oxford University Press.

Barley, S. R., \& Tolbert, P. S. (1997). Institutionalization and structuration: Studying the links between action and institution. Organization Studies, 18(1), 93-117

Battilana, J., \& Lee, M. (2014). Advancing research on hybrid organizing-Insights from the study of social enterprises. Academy of Management Annals, 8(1), 397-441

Benati, S. (2000). Informatica Trentina: Azienda decotta o miniera d'oro? Questo Trentino.

Benati S. (2001) Privatizzazione rinviata: Una sconfitta. Il monopolio di Informatica Trentina non ha più ragione di esistere e blocca lo sviluppo del settore informatico. Questo Trentino.

Bourdieu, P. (1996). The rules of art: Genesis and structure of the literary field. Stanford University Press.

Bovis, C. H. (2012). Public procurement in the EU: Jurisprudence and conceptual directions. Common Market Law Review, 49, 247

Brandsen, T., Van de Donk, W., \& Putters, K. (2005). Griffins or chameleons? Hybridity as a permanent and inevitable characteristic of the third sector. International Journal of Public Administration, 28(9-10), 749-765

Brenner, N. (2004). New State Spaces: Urban Governance and the Rescaling of Statehood. Oxford University Press.

Busco, C., Caglio, A., \& Scapens, R. W. (2015). Management and accounting innovations: Reflecting on what they are and why they are adopted. Journal of Management \& Governance, 19(3), 495-524

Busco, C., Giovannoni, E., \& Riccaboni, A. (2017). Sustaining multiple logics within hybrid organisations: Accounting, mediation and the search for innovation. Accounting, Auditing and Accountability Journal, 30(1), 191-216

Busco, C., \& Scapens, R. W. (2011). Management accounting systems and organisational culture. Qualitative Research in Accounting \& Management, 8(4), 320-357

Cafruny, A. W., \& Ryner, M. (Eds.). (2003). A ruined fortress?: Neoliberal hegemony and transformation in Europe. Rowman \& Littlefield Publishers.

Calliari, F. (2010). I rapporti (ravvicinati) tra i soggetti appartenenti al sistema pubblico provinciale con le società in house della Provincia autonoma di Trento.

Canales, R. (2014). Weaving straw into Gold: Managing organizational tensions between standardization and flexibility in microfinance. Organization Science, 25(1), 1-28

Caretto, E. (2002). Qualità dei servizi. Pubblica amministrazione e cittadinanza. (Vol. 3)Amaltea edizioni.

Cartel, M., Boxenbaum, E., \& Aggeri, F. (2019). Just for fun! How experimental spaces stimulate innovation in institutionalized fields. Organization Studies, 40(1), 65-92

Cinquini, L., \& Tenucci, A. (2010). Strategic management accounting and business strategy: A loose coupling? Journal of Accounting \& Organizational Change, 6(2), 228-259

Cintioli, F. (2014). The in-house providing companies in the Italian legal system. The goal of privatisation and the effects of people's will. Rivista Italiana Di Antitrust/italian Antitrust Review, 1(1), 26-36

Clarke, T., \& Pitelis, C. (Eds.). (2005). The political economy of privatization. Routledge.

Comba, M., \& Treumer, S. (Eds.). (2010). The in-house providing in European law (Vol. 1, pp. 165185). Djøf Forlag. (European Procurement Law Series).

Commission of the European Communities. (1995). White Paper Preparation of the Associated Countries of Central and Eastern Europe for Integration into the Internal Market of the Union, Brussels, 03.05:1995 COM (95) 163. Commission of the European Communities.

Commission of the European Communities. (1998). Public procurement in the European Union, 11.03.1998 COM (1998) 143 final. Commission of the European Communities.

Council Directive. (1992). Council directive 92/50/EEC of 18 June 192 relating to the coordination of procedures for the award of public service contracts. Official Journal of the European Communities, L, 209(35), 5

Cresswell, T. (2004). Place: A short introduction. Blackwell Publishing. 
Dacin, M. T., Dacin, P. A., \& Tracey, P. (2011). Social entrepreneurship: A critique and future directions. Organization Science, 22(5), 1203-1213

Dawson, P., \& Sykes, C. (2019). Concepts of time and temporality in the storytelling and sensemaking literatures: A review and critique. International Journal of Management Reviews, 21(1), 97-114

DiMaggio, P. J., \& Powell, W. W. (1991). The new institutionalism in organization analysis. University of Chicago Press.

Dubois, V. (2014). The fields of public policy. In Hilgers, Mangez (Eds.) Bourdieu's theory of social fields: Concepts and applications. The case of Belgium. Bourdieu's theory of social fields: Concepts and applications (pp. 199-220).

Dunn, M. B., \& Jones, C. (2010). Institutional logics and institutional pluralism: The contestation of care and science logics in medical education, 1967-2005. Administrative Science Quarterly, 55(1), 114-149

Ebrahim, A., Battilana, J., \& Mair, J. (2014). The governance of social enterprises: Mission drift and accountability challenges in hybrid organizations. Research in Organizational Behavior, 34, $81-100$

Furnari, S. (2014). Interstitial spaces: Microinteraction settings and the genesis of new practices between institutional fields. Academy of Management Review, 39(4), 439-462

Glynn, M. A., \& Lounsbury, M. (2005). From the critics' corner: Logic blending, discursive change and authenticity in a cultural production system. Journal of Management Studies, 42(5), 1031-1055

Granqvist, N., \& Gustafsson, R. (2016). Temporal institutional work. Academy of Management Journal, 59(3), 1009-1035

Greenwood, R., Oliver, C., Lawrence, T. B., \& Meyer, R. (Eds.). (2017). The Sage handbook of organizational institutionalism. (2nd ed.). Sage.

Henri, J. F. (2006). Organizational culture and performance measurement systems. Accounting, Organizations and Society, 31(1), 77-103

Huberman, A. M., \& Miles, M. B. (1994). Data management and analysis methods. In N. K. Denzin \& Y. S. Lincoln (Eds.), Handbook of qualitative research. (pp. 428-444). Sage Publications.

Italian law. (2003). Legge 24 novembre 2003, n. 326 “Conversione in legge, con modificazioni, del decreto-legge 30 settembre 2003, n. 269, recante disposizioni urgenti per favorire lo sviluppo e per la correzione dell'andamento dei conti pubblici".

Italian law. (2006). Legge 4 agosto 2006, n. 248 "Conversione in legge, con modificazioni, del decretolegge 4 luglio 2006, n. 223, recante disposizioni urgenti per il rilancio economico e sociale, per il contenimento e la razionalizzazione della spesa pubblica, nonché interventi in materia di entrate e di contrasto all'evasione fiscale".

Janssen, W. A. (2014). Public Procurement Law and in-house delivery of public services: Improving a paradox. When private actors contribute to public interests. (pp. 7-26). Eleven Publishing.

Jay, J. (2013). Navigating paradox as a mechanism of change and innovation in Hybrid Organizations. Academy of Management Journal, 56(1), 137-159

Kellogg, K. C. (2009). Operating room: Relational spaces and microinstitutional change in surgery. American Journal of Sociology, 115(3), 657-711

Koppell, J. G. (2003). The politics of quasi-government: Hybrid organizations and the control of public policy. Cambridge University Press.

Krippendorff, K. (2004). Content analysis: An introduction to its methodology. Sage.

Langley, A. N. N., Smallman, C., Tsoukas, H., \& Van de Ven, A. H. (2013). Process studies of change in organization and management: Unveiling temporality, activity, and flow. Academy of Management Journal, 56(1), 1-13

Lawrence, T. B., \& Dover, G. (2015). Place and institutional work: Creating housing for the hard-tohouse. Administrative Science Quarterly, 60(3), 371-410

Levina, N., \& Vaast, E. (2005). The emergence of boundary spanning competence in practice: Implications for implementation and use of information systems. MIS Quarterly, 29, 335-363

Local convention. (2006). Schema di convenzione per la governance della società di sistema, ai sensi degli articoli 33, comma 7 ter e 13, comma 2, lettera b) della legge provinciale, n. 3, 16/06/2006. Local convention.

Local Council. (2000). Resoconto integrale seduta straordinaria, Consiglio della Provincia autonoma di Trento 06/03/2000. Local Council.

Local Council. (2001). Resoconto integrale seduta antimeridiana, Consiglio della Provincia autonoma di Trento, 31/05/2001. Local Council. 
Local Government. (2007). Verbale di deliberazione della giunta provinciale, Registro delibere $n$. 2200, 12/10/2007. Local Government.

Local Government. (2008). Verbale di deliberazione della giunta provinciale, Registro delibere n. 468, 29/02/2008. Local Government.

Local Government. (2009). Verbale di deliberazione della giunta provinciale, Registro delibere $n .2893$ del 30/11/2009. Local Government.

Local law. (1980). Istituzione di un sistema informativo elettronico provinciale, 6 maggio 1980, $n$. 10.

Local law. (2006). Norme in materia di governo dell'autonomia del Trentino, 16 giugno 2006, $n$. 3.

Mair, J., Mayer, J., \& Lutz, E. (2015). Navigating institutional plurality: Organizational governance in hybrid organizations. Organization Studies, 36(6), 713-739

Mangez, E., \& Liénard, G. (2015). The field of power and the relative autonomy of social fields. The case of Belgium. In Hilgers, Mangez (Eds.) Bourdieu's theory of social fields: Concepts and applications. (pp. 183-197).

Manunza, E., \& Berends, W. J. (2013). Social services of general interest and the EU public procurement rules. Social services of general interest in the EU. (pp. 347-384). TMC Asser Press.

Market Directive. (2006). Directive 2006/123/EC of the European Parliament and of the Council of 12 December 2006 on services in the internal market. Market Directive.

Ménard, C. (2004). The economics of Hybrid Organizations. Journal of Institutional and Theoretical Economics, 160(3), 345-376

Mersland, R., \& Strøm, R. Ø. (2010). Microfinance mission drift? World Development, 38(1), 28-36

Meyer, J. W., \& Rowan, B. (1977). Institutionalized Organizations: Formal structure as myth and ceremony. American Journal of Sociology, 83(2), 340-363

Micelotta, E., Lounsbury, M., \& Greenwood, R. (2017). Pathways of institutional change: An integrative review and research agenda. Journal of Management, 43(6), 1885-1910

Minkoff, D. C. (2002). The emergence of Hybrid Organizational Forms: Combining identity-based service provision and political action. NonProfit and Voluntary Sector Quarterly, 31(3), 377-401

Monteduro, F. (2014). Public-private versus public ownership and economic performance: evidence from Italian local utilities. Journal of Management \& Governance, 18(1), 29-49

Muraro, G. (2008). Water services and water policy in Italy. Sustainable development and environmental management. (pp. 65-80). Springer.

Myers, M. D. (2013). Qualitative research in business and management. Sage.

Nicholls, A. (2009). We do good things, don't we?' 'Blended value accounting' in social entrepreneurship. Accounting, Organizations and Society, 34(6/7), 755-769

Nigam, A., \& Ocasio, W. (2010). Event attention, environmental sensemaking, and change in institutional logics: An inductive analysis of the effects of public attention to Clinton's health care reform initiative. Organization Science, 21(4), 823-841

O’Dwyer, B. (2004). Qualitative data analysis: Illuminating a process for transforming a 'messy' but 'attractive' 'nuisance.' In C. Humphrey \& B. Lee (Eds.), The real life guide to accounting research. A behind the scene view of using qualitative research methods. (pp. 391-407). Elsevier Science.

Pache, A. C., \& Santos, F. (2013). Inside the hybrid organization: Selective coupling as a response to competing institutional logics. Academy of Management Journal, 56(4), 972-1001

Pancia, S. (2001). La strana privatizzazione di InformaticaTrentina. L'idea è giusta; ma il modo in cui si sta procedendo è incredibile. Questo Trentino.

Pänke, J. (2019). Liberal empire, geopolitics and EU strategy: Norms and interests in European foreign policy making. Geopolitics, 24(1), 100-123

Paris, S. (2000). Dellai, i suoi disegni, e quelli che cercano di fermarlo. Questo Trentino.

Ponte, D., Pesci, C., \& Camussone, P. F. (2017). Between mission and revenue: Measuring performance in a hybrid organization. Managerial Auditing Journal, 32(2), 196-214

Quattrone, P. (2015). Governing social orders, unfolding rationality, and Jesuit accounting practices: A procedural approach to institutional logics. Administrative Science Quarterly, 60(3), 411-445

Raik, K. (2016). Liberalism and geopolitics in EU-Russia relations: Rereading the "Baltic factor." European Security, 25(2), 237-255

Ramus, T., \& Vaccaro, A. (2017). Stakeholders matter: How social enterprises address mission drift. Journal of Business Ethics, 143(2), 307-322

Ramus, T., Vaccaro, A., \& Brusoni, S. (2017). Institutional complexity in turbulent times: Formalization, collaboration, and the emergence of blended logics. Academy of Management Journal, 60, 1253-1284 
Reggi, L., \& Ricci, C. A. (2014). Il ruolo delle società in house nel coordinamento delle politiche regionali per l'e-government. Economia e Politica Industriale, 3, 159-177

Reinecke, J., \& Ansari, S. (2015). When times collide: Temporal brokerage at the intersection of markets and developments. Academy of Management Journal, 58(2), 618-648

ServiceCo. (2007). 2007 Annual Report. Financial Statements.

ServiceCo. (2008). 2008 Annual Report. Financial Statements.

ServiceCo. (2009). 2009 Annual Report. Financial Statements.

ServiceCo. (2010). 2010 Annual Report. Financial Statements.

ServiceCo. (2011). 2011 Annual Report. Financial Statements.

ServiceCo Balanced Scorecard. (2011) Balanced Scorecard 2006-2010.

ServiceCo Balanced Scorecard. (2012). Balanced Scorecard 2007-2011.

ServiceCo Balanced Scorecard. (2013). Balanced Scorecard 2008-2012.

ServiceCo Strategic plan. (2008). Strategic and industrial plan 2008-2010.

Skelcher, C., \& Smith, S. R. (2015). Theorizing hybridity: Institutional logics, complex organizations, and actor identities: The case of nonprofits. Public Administration, 93(2), 433-448

Slawinski, N., \& Bansal, P. (2015). Short on time: Intertemporal tensions in business sustainability. Organization Science, 26(2), 531-549

Statute. (1983). Statute of the firm. Statute.

Statute. (2006). Statute of the firm. Statute.

Suddaby, R. (2010). Challenges for institutional theory. Journal of Management Inquiry, 19(1), 14-20

Suddaby, R. (2015). Can institutional theory be critical? Journal of Management Inquiry, 24(1), 93-95

Teixeira, M. G., Roglio, K. D. D., \& Marcon, R. (2017). Institutional logics and the decision-making process of adopting corporate governance at a cooperative organization. Journal of Management \& Governance, 21(1), 181-209

Thornton, P. H. (2004). Markets from culture: Institutional logics and organizational decisions in higher education publishing. Stanford University Press.

Thornton, P. H., \& Ocasio, W. (1999). Institutional logics and the historical contingency of power in organizations: Executive succession in the higher education publishing industry, 1958-1990. American Journal of Sociology, 105(3), 801-843

Thornton, P. H., \& Ocasio, W. (2008). Institutional logics. The Sage Handbook of Organizational Institutionalism, 840, 99-128

Thornton, P. H., Ocasio, W., \& Lounsbury, M. (2012). The Institutional logics perspective: A new approach to culture, structure, and process. Oxford University Press.

Unpublished company presentation. (2009). Il progetto "collaborazione territoriale ict" di Provincia autonoma di Trento quale fattore di sviluppo del sistema locale delle imprese ICT, ForumPA, 13/05/2009, Rome.

Unpublished company presentation. (2012). Informatica Trentina, essere "società di sistema": le iniziative per il comparto degli Enti Locali, Trento, 05/04/2012.

Ursi, R. (2005). Le società per la gestione dei servizi pubblici locali a rilevanza economica tra outsourcing e in house providing. Diritto Amministrativo, 1, 179-209

Wehlander, C. (2016). Services of general economic interest as a constitutional concept of EU law. TMC Asser Press.

Yin, R. K. (2003). Case study research: design and methods, Applied social research methods series. Sage Publications Inc.

Zhang, Y. Z., Hoque, Z., \& Isa, C. R. (2015). The effects of organizational culture and structure on the success of activity-based costing implementation. Advances in Management Accounting, 25, 229-257

Publisher's Note Springer Nature remains neutral with regard to jurisdictional claims in published maps and institutional affiliations.

Diego Ponte is Associate Professor of Organization Science at the Department of Economics and Management of the University of Trento, Italy. His research interests lie in the areas of Digital Transformation, Information and Knowledge Management, and Organizational Change. 
Caterina Pesci is Assistant Professor of Accounting at the Department of Economics and Management of the University of Trento, Italy. Her research interests and publications lie in the areas of Accounting, Accountability, Social and Environmental Accounting and Reporting, Governance and Non for Profit Organizations. 